\title{
ENVIRONMENTAL SYSTEM ENGINEERING (ESE): MODELING AND OPTIMIZATION OF A TEXTILE EFFLUENT DISCOLORATION PROCESS BY SORPTION
}

\author{
CARMEN ZAHARIA ${ }^{1 *}$ \\ 1 "Gheorghe Asachi" Technical University of Iasi, Faculty of Chemical Engineering \\ and Environmental Protection, Department of Environmental Engineering and \\ Management, 73 Prof. Dr. Docent D. Mangeron Blvd, 700050 Iasi, Romania
}

\begin{abstract}
Nowadays, an interdisciplinary field of engineering that focuses on analytical and/or empirical models represented by mathematical, data-driven and biotic structures combined with physical, biological and ecological processes in water, air and eco-systems is developing, i.e. environmental system engineering (ESE). In this system, environmental modeling and process optimization acts together for solving problems with environmental systems, especially for minimizing pollution, or eco-toxicological effects.

The present paper proposes the study of modeling and optimization of an environmental system (i.e. textile wastewater treatment system based on sorption onto indigene peat) for its discoloration (consequently, decreasing of color, organic and inorganic loads of effluent discharged in aquatic receptor, or inside reused). All performed laboratory tests consisted in 22 hours-sorption experiments onto peat applied for a real colored textile effluent, organized with respecting of an empirical planning by a central active composite rotatable $2^{3}$ order design, considering as independent variables the peat dose $\left(\mathrm{X}_{1}\right), \mathrm{pH}\left(\mathrm{X}_{2}\right)$, and temperature $\left(\mathrm{X}_{3}\right)$, and as optimization criterion, or decision function, the discoloration degree, or color removal $(\mathrm{Y},[\%])$. The mathematical model was found adequate for the textile wastewater treatment, and the optimal operational conditions for highest discoloration efficiency were proposed.
\end{abstract}

Keywords: empirical design, discoloration degree, model, optimization, textile effluent, three independent variables, wastewater treatment system

\section{INTRODUCTION}

The process systems' engineering focuses on new trends and challenges consisting of environmental-related matters/ issues (e.g., the urban, drinking and/or industrial water cycle, production waste, environmental pollution, environmental impact and risk produced etc.), chemical-based products, energy, physicochemical-systems or biosystems engineering, and enterprise-wide optimization such as multi-scale modeling, mixture/hybrid models, energy and sustainability, fresh drinkable water diminishing or crisis, wastewater and/or stormwater management, climate change issues, $\mathrm{CO}_{2}$ storage, among others. Moreover, it is suggesting the need of integrated system approach for development of industrial nano-, meso- and macro-scale processes, and also market products and services considering the economic, social, technical and also environmental constraints. In addition, special attention is still giving to the use of resources (usual/common, or new ones) to minimize water, energy and air pollution but also eco-toxicological effects in the environment [1-2].

\footnotetext{
*Corresponding author, email: $\underline{\operatorname{czah} @ \text { ch.tuiasi.ro }}$

(c) 2015 Alma Mater Publishing House
} 
Environmental systems engineering (ESE), as an interdisciplinary field, is based on environmental modeling and process optimization focused on solving the environmental pollution problems by optimizing the existing processes or services with minimal costs (i.e. increasing treatment capacities of wastewater treatment plants with min $10 \%-30 \%$ by optimizing instrumentation, control and automation of treatment processes thus saving of 6 $\%-10 \%$ from operating costs, and remarkably shorting payback times, or adapting it to new changes, or equipment/installations in treatment processes working at optimal operational parameters and regime with minimal costs) [3]. A general schematic representation of ESE concept, particularly applied for a wastewater treatment system, is illustrated in Figure 1 [1].

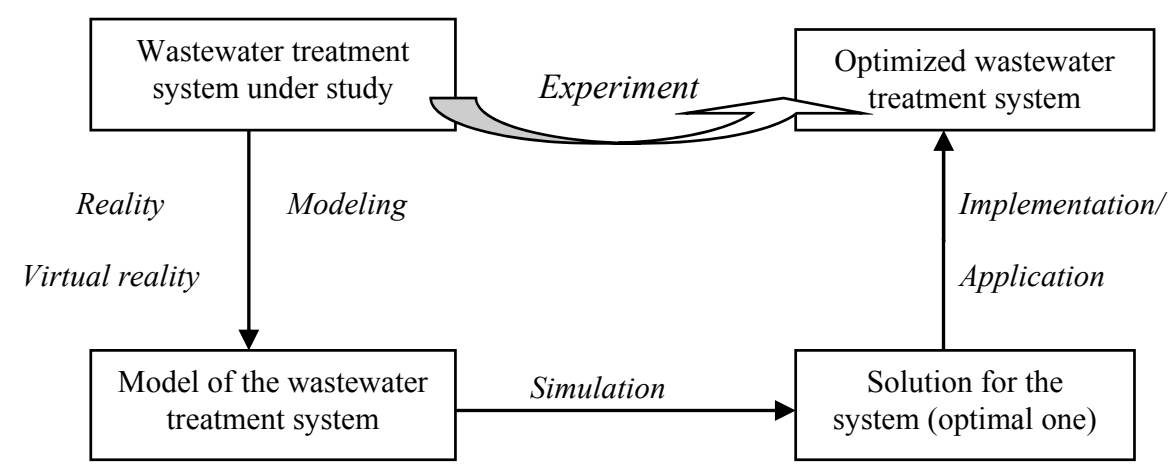

Fig. 1. Environmental system engineering (ESE) concept, particularly for a wastewater treatment system.

Reliable wastewater treatment is necessary in all industrial processing/manufacturing industry. Therefore, efficient modeling and monitoring methods are becoming very important in each industrial process performance. Improving wastewater treatment performance requires accumulation and very good fundamental and practical understanding (accurate knowledge) of the treatment processes, fact that imposes the necessity of mathematical modeling and simulation [1]. The designing and operating of functional wastewater treatment systems are considered as knowledge management tools, although the optimization issue is very problematic due to model complexity (i.e. many components, kinetic and stoichiometric parameters etc.) [3]. Therefore, the key parameters influencing the removal efficiency must be well selected, prediction model efficiency and sensitivity analysis improved, because it is difficult to simultaneously consider all selected variables when is predicting the results at the same time.

In this context, the most indicated practical problems and conditions existing in wastewater treatment systems must be studied by advanced analytical, technical and system analysis tools, but also mathematical modeling and numerical simulation, being beneficial for both scientists and engineers, helping them to bridge the gap between science and engineering in wastewater treatment technologies, among others [4].

The principal objectives of an industrial wastewater treatment are the decomposition of dissolved organic and inorganic compounds in simpler ones, or even $\mathrm{CO}_{2}$ and $\mathrm{H}_{2} \mathrm{O}$, but also the separation of different dangerous and/or persistent constituents which can damage the ecosystem nearby. Due to its importance and large number of existing installations adaptable for different specific treatment stages, a huge number of research works have been carried out in the field of treatment systems by adsorption process (i.e. simple and cheap 'end-of-pipe' separation system solution) on commercial adsorbents (i.e. activated carbon, exchangeable resins, different microporous or macroporous polymers of organic, or inorganic origin), or ,low cost' materials (i.e. natural or synthesis production wastes or by-products, natural materials, or residues) [5-10].

A high number of research works reported that various solid materials can adsorb different organic substances (e.g., dyes, alcohols, amino acids, polymers, persistent organic compounds etc.), heavy metal ions, and other contaminants from different industrial effluents by adsorptive processes of physical (physical adsorptions), chemical (chemisorptions) or biological nature (biosorptions), or mixed/hybrid adsorptive processes of all these, respectively [5-12]. From cost-efficiency and performance reasons, the cheap adsorbents which contain high quantities of carbon in their chemical structure, available in nature, or as production wastes, can remove different polluting loads from effluents (especially, industrial effluents), and recover useful retained species from the high adsorptive material due to its simple regeneration capacity. 
This paper continues the author research work in modeling (especially, in using an empirical experimental planning by an active central composite rotatable $2^{3}$ order design, considering three independent variables, and discoloration degree as optimization criterion) [13-15], or other empirical modeling reports [16-22], monitoring (all imposed technological operating parameters in all treatment stages and functional equipments/installations, especially of peat dose, $\mathrm{pH}$, temperature, sorption time, agitation regime, effluent flowing rate etc.), control ( $\mathrm{pH}$, suspended solids, color and/or organics removal, flow rate, temperature, other specific operating parameters etc.) and optimizing of wastewater treatment system based on sorption (single-stage treatment followed by sedimentation) onto natural peat as the given sorbent for a textile wastewater treatment.

\section{EXPERIMENTAL SETUP}

\subsection{Wastewater treatment system characterization}

In the manufacturing of textile cotton fabrics are producing various types of industrial wastewaters containing azo dyes (e.g., Remazol Arancio 3R, $33 \mathrm{~g} / \mathrm{L}$, and Remazol Rose RB, $22 \mathrm{~g} / \mathrm{L})$, tensides $(3 \mathrm{~g} / \mathrm{L}), \mathrm{Na}_{2} \mathrm{CO}_{3}(20 \mathrm{~g} / \mathrm{L}), \mathrm{NaOH}$ $(5 \mathrm{~g} / \mathrm{L})$, and other auxiliaries [5-9]. These wastewaters are exceeding the admissible limits for a lot of quality indicators (i.e. color, $\mathrm{COD}, \mathrm{BOD}_{5}$, total dissolved solids, suspended solids, salts, etc.) being necessary its treatment before final discharge or inside reuse, by at least a primary treatment developed as simple as possible (ideally in one single-stage treatment) such as adsorption [5-9].

In all experiments was worked with Sphagnum moss peat, as natural fibrous adsorptive material, collected from Poiana Stampei (Romania), and consisting of its main constituents: cellulose, lignin, humic and fulvic acids, different polar functional groups such as carboxyl, carbonyl, phenolic and enolic hydroxyl groups, etc. Some physical and chemical characteristics of the moss peat are: colour - brown; organic carbon content - $49 \mathrm{w} \%$; total proteins - $7.8 \mathrm{w} \%$; ash - $3.44 \mathrm{w} \%$; $\mathrm{pH}-3.5$; specific surface area $-192 \mathrm{~m}^{2} / \mathrm{g}$ [7, 9-10, 12]. It was worked with fraction of peat dried in air with particle size lower than $1-2 \mathrm{~mm}$ (after preliminary screening).

All sorption experiments were performed in duplicate using a series of shake-flask tests by 'batch' technique (specific static regime) at $\mathrm{pH}(2.66,3.5,4.0$, and 4.34$)$ and different temperatures $\left(6.5^{\circ} \mathrm{C}, 20^{\circ} \mathrm{C}, 28^{\circ} \mathrm{C}\right.$, and 33.5 ${ }^{\circ} \mathrm{C}$ ): samples of moss peat (corresponding to sorbent dose of 10.54-37.46 [g/L], or 0.264-0.936 [g per $\left.25 \mathrm{~mL}\right]$ ) were shaken for 3-5 min with $25 \mathrm{~mL}$ of real textile wastewater in $100 \mathrm{~mL}$ Erlenmeyer flasks, and after let to act without stirring for more than 22 hours, or 24 hours of adsorption. Samples from separated supernatant (,clear' aqueous treated or not effluent with peat) were collected for analytical analysis (mainly colour, $\mathrm{pH}$, total organics, fixed residues etc.).

The adsorption performance was evaluated considering the treated wastewater discoloration, being expressed as a discoloration degree, or colour removal degree [\%] (equation 1) [10, 12].

$$
\mathrm{DD}[\%]=\left[\left(\mathrm{C}_{0}-\mathrm{C}\right) / \mathrm{C}_{0}\right] * 100
$$

where, $C_{0}$ and $C$ are the initial and final color of wastewater sample (treated or not) after min 22 hours, or 24 hours of adsorption, [HU], or sample adsorption at $456 \mathrm{~nm}$ under a blank with distillate water.

\subsection{Analytical analysis methods}

The $\mathrm{pH}$ of treated or not textile wastewater was adjusted to a desired value (2.66-4.34) by addition of $\mathrm{HCl} 0.1 \mathrm{M}$ solution, and directly measuring the $\mathrm{pH}$ value with the HACH One Laboratory $\mathrm{pH}$-meter.

The colour of textile wastewater was expressed by the absorbance under a blank with distillate water at the three characteristic wavelengths $(436,525$ and $620 \mathrm{~nm})$ as in SR ISO 7887-97 standard, or by the Hazen color index which represents the conversion of absorbance at $456 \mathrm{~nm}$ into Hazen units [HU] (i.e. $0.069\left(\mathrm{~A}_{456}\right)$ corresponds to $50[\mathrm{UH}])$ [5-11]. For industrial wastewater is obligatory measuring of absorbance at $436 \mathrm{~nm}$ in supernatant (apparent color) or filtrate (real color). The absorbance measurements were performed with SP 830 Plus Spectrophotometer, Metertech Inc.Version 1.06 (a digital microprocessor controlled instrument providing photometric absorbance, transmittance and concentration measurements in the wavelength range of 320 to 999 $\mathrm{nm})$.

The chemical oxygen demand (COD-Cr) was determined with the spectrophotometer-based method by absorbance measurement at $600 \mathrm{~nm}$ with the same SP-830 Plus Spectrophotometer of treated sample by oxidation $(2 \mathrm{~h}, 150$ 
${ }^{\circ} \mathrm{C}$; i.e. oxidation in concentrated $\mathrm{H}_{2} \mathrm{SO}_{4}$ medium with $0.25 \mathrm{~N} \mathrm{~K}_{2} \mathrm{Cr}_{2} \mathrm{O}_{7}$ solution, in presence of specific catalyst$\mathrm{HgSO}_{4}$, and chloride inhibitory agent- $\mathrm{Ag}_{2} \mathrm{SO}_{4}$ ) [9].

The content of total suspended solids (TSS) and turbidity (T) were measured directly at DRELL 2000 Spectrophoto-meter (HACH Company) operating the specific tests: \#630 for TSS, and \#750 for turbidity (T) [79].

The concentrations of chlorides, nitrates, nitrites, total nitrogen, total phosphorus, fixed residues, phenol, and different heavy metal ions were determined using internationally approved standards and reference materials based on spectrophotometer analysis methods, adapted for the specific test programs and reagent kits of DRELL 2000 spectrophotometer, HACH Company [7, 9].

\subsection{Modeling and optimization methodology}

The independent variables in all adsorption experiments onto moss peat applied for the same textile wastewater were considered to be: the sorbent dose $\left(Z_{1}\right.$, [g per $25 \mathrm{~mL}$ ], or $\left.[\mathrm{g} / \mathrm{L}]\right), \mathrm{pH}\left(Z_{2}, \mathrm{pH}\right.$ unit) and temperature $\left(Z_{3},\left[{ }^{\circ} \mathrm{C}\right]\right)$. As optimization criterion, or decision/response function was chosen the discoloration degree, or colour removal $(\mathrm{Y},[\%])$.

The mathematical model used was of " $n=3$ " variables applied according to the experimental planning matrix of a central active composite rotatable $2^{3}$ order design, expressed by equation 2 [13-15].

$$
Y=a_{0}+\sum a_{i .} x_{i}+\sum a_{i} x_{i}^{2}+\sum a_{i j} x_{i} x_{j}
$$

where, $Y$ represents the decision/response function, or optimization criterion; $x_{i}, x_{j}, x_{i i}, x_{i j}$ - the coded variables of the system, and $a_{0}, a_{i}, a_{j}, a_{i j}$ - the model coefficients $(i, j=1,2,3)$.

The model coefficients are calculated using the least square fitting of model (empirical model) obtained in the design points (20 experimental points). The central active composite rotatable design has the advantage of no excessive experiments referring to the coefficients' number to be determined (i.e. 20 experiments: $N^{\mathrm{F}}=2^{3}$ factorial experiments, performed at the corner of cube which represents the experimental data area; $N_{\mathrm{a}}=2 \times 3$ axial experiments, carried out on the axes, at a distance of $\pm \alpha_{i}$ from the centre, calculated such as to obtain rotability; $N_{0}$ $=6$ experiments at the centre of experiment field in order to allow calculation of an independent estimation of 'pure' experimental error, or reproducibility variance) [13-22].

In all sorption experiments were attributed values (levels) to each $Z_{i}$ independent variable, in accordance with its $Z_{i 0}$ basic value and $\Delta Z_{i 0}$ variation step. The upper level is obtained by adding the variation step at the basic value, while the lower level, by subtraction of the variation step from the basic value of independent variable. $X_{i}$ coded value of $Z_{i}$ is calculated with equation 3 [13-22]:

$$
X_{i}=\left(Z_{i}-Z_{i 0}\right) / \Delta Z_{i 0}
$$

The $X_{i}$ coded values can be $0, \pm 1, \pm \alpha_{i}$ (i.e. $\alpha_{i}= \pm 1.682$ for a central active composite rotatable $2^{3}$ design). The Fisher constant $(F)$, multiple correlation coefficient $\left(R_{Y x \mid x 2 \times 3}\right)$, or Fisher test $\left(F_{C}\right)$, defined by equations presented in Table 1, were also determined for establishing the correlation between the decision/response function (optimization criterion), and the three independent variables as in equation $2[5,13-16]$. The deviation between the model-calculated data and experimental ones is recommended to vary in range of $-10 \%$ and $+10 \%$ for a very good accordance.

Table 1. Calculation formulas for Fisher constant $(F)$, multiple correlation coefficient $\left(R_{Y x I x 2 \times 3}\right)$, and Fisher test $\left(F_{c}\right)$.

\begin{tabular}{|c|c|c|}
\hline Fisher constant $-F$ & Multiple correlation coefficient $-R_{Y_{x} I x 2 \times 3}$ & Fisher test $-F_{c}$ \\
\hline$F=\frac{(n-1) \cdot \sum_{i=1}^{n}\left(Y_{e i}-\overline{Y_{e}}\right)}{(k-1) \cdot \sum_{i=1}^{k}\left(Y_{e k 1}-\overline{\left.Y_{e k}\right)}\right.}$ & $R_{Y_{x 1, X 2, X 3}}=\sqrt{1-\frac{\sum_{i=1}^{n}\left(Y_{e i}-Y_{c i}\right)^{2}}{\sum_{i=1}^{n}\left(Y_{e i}-\overline{\left.Y_{e}\right)^{2}}\right.}}$ & $F_{C}=\frac{n-b-1}{b} \cdot \frac{R_{Y_{x 1 \times 2 \times 3}}^{2}}{1-R_{Y \times 1 \times 2 \times 3}^{2}}$ \\
\hline
\end{tabular}


where $Y_{e i}$-experimental results, $\overline{Y_{e}}$ - average value of experimental results, $Y_{e k i}$ - experimental results in center of experimental design planning, $\overline{Y_{e k}}$ - average value of experimental results in central point of design planning, $Y_{c l}$ - calculated results with proposed model, $n$ - number of experiments, $k$ - number of experiments in the central point of experimental design, $b$ - number of independent variables.

\section{RESULTS AND DISCUSSION}

One important primary objective of industrial wastewater treatment is the separation of different constituents which can damage the ecosystem, and also the decomposition of dissolved organic and inorganic compounds in simpler ones (or $\mathrm{CO}_{2}, \mathrm{H}_{2} \mathrm{O}$ ), among others. The principal characteristic quality indicators of studied textile wastewater are presented in Table 2 [9].

Table 2. The main quality indicators of studied textile wastewaters [9].

\begin{tabular}{|c|c|c|c|c|c|}
\hline Quality indicators & $\begin{array}{c}\text { Measured value, } \\
{[\mathrm{mg} / \mathrm{L}]}\end{array}$ & $\begin{array}{c}\text { M.A.C. } \\
{[\mathrm{mg} / \mathrm{L}]}\end{array}$ & Quality indicators & $\begin{array}{c}\text { Measured } \\
\text { value, }[\mathrm{mg} / \mathrm{L}]\end{array}$ & $\begin{array}{c}\text { M.A.C. } \\
{[\mathrm{mg} / \mathrm{L}]}\end{array}$ \\
\hline $\mathrm{pH}$ & $7.30-7.49$ & $6.50-8.50$ & Total phosphorus $(\mathrm{P})$ & $4.54-5.72$ & 1 \\
\hline Colour, HU & $389.86-436.43$ & 50 & Extractible substances & $45.44-61.67$ & 20 \\
\hline Suspended solids & $289-336$ & $35(60)$ & Total nitrogen $(\mathrm{N})$ & $9.80-10.12$ & 10 \\
\hline Turbidity, FTU & $85-93$ & - & Ammonia $\left(\mathrm{NH}_{4}^{+}\right)$ & $2.10-2.45$ & 2 \\
\hline Fixed residues & $3600-4000$ & 1000 & Sulfates $\left(\mathrm{SO}_{4}{ }^{2-}\right)$ & $365.81-382.34$ & 600 \\
\hline $\mathrm{COD}_{\mathrm{Cr}, \mathrm{mg} \mathrm{O}_{2} / \mathrm{L}}$ & $564.12-665.0$ & 125 & Chlorides $(\mathrm{Cl})$ & $98.56-100.23$ & 70 \\
\hline BOD $_{5}, \mathrm{mg} \mathrm{O}_{2} / \mathrm{L}$ & $322.10-386.0$ & 25 & Phenol index & $2.623-3.261$ & 0.30 \\
\hline Synthetic detergents & $1.56-1.78$ & 0.50 & Heavy metals & $<5$ & $<2$ \\
\hline
\end{tabular}

* MAC - Maximum Admissible Concentration, according with Romanian Government Decision No. 352/2005Technical Norms for Treated Wastewater Discharged in Natural Aquatic receptors (such as Natural Surface Water Resources) (NTPA 001)

It can conclude that some values of the measured physical-chemical quality indicators, presented in Table 2, were exceeding the maximum admissible concentrations (1.05-10.9 times higher) (e.g., color, suspended solids, fixed residues, $\mathrm{COD}-\mathrm{Cr}, \mathrm{BOD}_{5}$, total phosphorus, ammonia, detergents, extractible substances, phenol index, some heavy metals), therefore, an wastewater treatment stage was obligatory, and must be implemented easily in the existent operating regime, with minimum financial and technical (capital) efforts. A possible viable WW treatment solution is an adsorption stage onto a high adsorptive natural material, as moss peat, among others.

In this context, the paper proposes a modeling and optimization study by adsorption onto moss peat applied for a real textile wastewater with the main target of wastewater discoloration for reuse in the rinsing stage of cotton dyed fabrics (three cycles), and after directly discharged in natural aquatic receptor nearby. The real $\left(Z_{i 0}\right)$ and coded basic $\left(X_{i 0}\right)$ values for the three studied independent variables of adsorption treatment stage onto moss peat are shown in Table 3 , together with their variation steps $\left(\Delta Z_{i 0}\right)$.

The textile collected wastewater samples of $25 \mathrm{~mL}$ were contacted with different doses (amounts) of moss peat at $\mathrm{pH}$ 2.66-4.34, different temperatures $\left(6.5^{\circ} \mathrm{C}, 20^{\circ} \mathrm{C}, 28^{\circ} \mathrm{C}\right.$ and $\left.43.5^{\circ} \mathrm{C}\right)$, under initial continuous stirring $(50 \mathrm{rpm})$ of 3-5 min, and studied related to a minimum 22 hours- or 24 hours-static adsorption stage, based on the experimental planning design presented in Table 4 (the experimental design matrix).

Table 3. The codification of independent variables in the central active composite rotatable $2^{3}$ design.

\begin{tabular}{|l|c|c|c|c|}
\hline Variable/ value & $\begin{array}{c}\text { Real variable } \\
\left(Z_{i}\right)\end{array}$ & $\begin{array}{c}\text { Coded variable } \\
\left(X_{i}\right)\end{array}$ & $\begin{array}{c}\text { Real basic variable } \\
\left(Z_{i 0}\right)\end{array}$ & $\begin{array}{c}\text { Variation step } \\
\left(\Delta Z_{i 0}\right)\end{array}$ \\
\hline Peat dose, $[\mathrm{g}$ per $25 \mathrm{~mL}]$ & $\mathrm{Z}_{1}$ & $\mathrm{X}_{1}$ & 0.60 & 0.20 \\
\hline $\mathrm{pH}$ & $\mathrm{Z}_{2}$ & $\mathrm{X}_{2}$ & 3.5 & 0.50 \\
\hline Temperature,$\left[{ }^{\circ} \mathrm{C}\right]$ & $\mathrm{Z}_{3}$ & $\mathrm{X}_{3}$ & 20 & 8 \\
\hline
\end{tabular}

The proposed model for adsorption onto moss peat is presented below considering all coefficients (equation 4), or without $X_{1} X_{3}$ term (equation 5) considered as insignificant (due to results after Student test application $(t)$, Table 
5) [14-15]. The calculation of model coefficients was performed with some proper formulas, well-known in mathematical statistics and described in-detail in other previous papers [5, 14-15].

$\mathrm{Y}=55.482+6.761 \mathrm{X}_{1}-2.606 \mathrm{X}_{2}+9.523 \mathrm{X}_{3}+0.925 \mathrm{X}_{1}^{2}+1.364 \mathrm{X}_{2}^{2}-1.791 \mathrm{X}_{3}^{2}-1.539 \mathrm{X}_{1} \mathrm{X}_{2}-0.506 \mathrm{X}_{1} \mathrm{X}_{3}+1.143 \mathrm{X}_{2} \mathrm{X}_{3}$

The calculated value for the Fisher constant is $F=832.0136$ for $Y$ (color removal), and the statistical value (from table) is $F_{\text {tab }}=4.6$ (for $\alpha=99, v_{l}=\mathrm{n}-1=19, v_{2}=\mathrm{k}-1=2$, where $n$ is the number of experiments, and $k$ is the independent variable number). Because $F>F_{\text {tab }}$ it can be considered that the deviation of experimental data from the average value is due to influence of independent variables towards decision/response function, not of experimental errors.

$$
\mathrm{Y}=55.482+6.761 \mathrm{X}_{1}-2.606 \mathrm{X}_{2}+9.523 \mathrm{X}_{3}+0.925 \mathrm{X}_{1}^{2}+1.364 \mathrm{X}_{2}^{2}-1.791 \mathrm{X}_{3}^{2}-1.539 \mathrm{X}_{1} \mathrm{X}_{2}+1.143 \mathrm{X}_{2} \mathrm{X}_{3}
$$

The multiple correlation coefficient is $R_{Y X I X 2 X 3}=0.8842$, demonstrating the high importance of all independent variables in variation of decision function (optimization criterion) in the considered experimental variation field.

The calculated Fisher test value is: $F_{C}=40.723$, being higher than the statistical value (from table) of $F_{C, \text { tab }}=6.59$ for freedom degree of $v_{l}=\mathrm{n}-\mathrm{k}-1=16$ and $v_{2}=\mathrm{k}=3$, demonstrating that the independent variables had a significant influence on the decision/response function (optimization criterion). The correlation between the experimental and model-calculated data is presented in Table 4.

Table 4. Experimental planning matrix in central active composite rotatable $2^{3}$ order design.

\begin{tabular}{|c|c|c|c|c|c|c|c|c|c|}
\hline Exp. No. & $\mathrm{Z}_{1}$ & $\mathrm{Z}_{2}$ & $\mathrm{Z}_{3}$ & $\mathrm{X}_{1}$ & $\mathrm{X}_{2}$ & $\mathrm{X}_{3}$ & $\mathrm{Y}_{\mathrm{e}}[\%]$ & $\mathrm{Y}_{\mathrm{c}}[\%]$ & Deviation [\%] \\
\hline 1 & 0.40 & 3.0 & 12 & -1 & -1 & -1 & 40.82 & 41.904 & -2.656 \\
\hline 2 & 0.80 & 3.0 & 12 & 1 & -1 & -1 & 51.56 & 58.504 & -13.468 \\
\hline 3 & 0.40 & 4.0 & 12 & -1 & 1 & -1 & 44.56 & 37.488 & 15.871 \\
\hline 4 & 0.80 & 4.0 & 12 & 1 & 1 & -1 & 50.12 & 47.932 & 4.366 \\
\hline 5 & 0.40 & 3.0 & 28 & -1 & -1 & 1 & 58.64 & 58.668 & -0.048 \\
\hline 6 & 0.80 & 3.0 & 28 & 1 & -1 & 1 & 68.33 & 75.268 & -10.154 \\
\hline 7 & 0.60 & 4.0 & 28 & -1 & 1 & 1 & 67.92 & 58.816 & 13.404 \\
\hline 8 & 0.80 & 4.0 & 28 & 1 & 1 & 1 & 70.48 & 69.26 & 1.731 \\
\hline 9 & 0.264 & 3.5 & 20 & -1.682 & 0 & 0 & 38.32 & 46.727 & -21.939 \\
\hline 10 & 0.936 & 3.5 & 20 & 1.682 & 0 & 0 & 76.24 & 69.471 & 8.879 \\
\hline 11 & 0.60 & 2.66 & 20 & 0 & -1.682 & 0 & 73.18 & 63.724 & 12.921 \\
\hline 12 & 0.60 & 4.34 & 20 & 0 & 1.682 & 0 & 43.86 & 54.958 & -25.302 \\
\hline 13 & 0.60 & 3.5 & 6.5 & 0 & 0 & -1.682 & 34.22 & 34.397 & -0.518 \\
\hline 14 & 0.60 & 3.5 & 33.5 & 0 & 0 & 1.682 & 64.98 & 66.432 & -2.236 \\
\hline 15 & 0.60 & 3.5 & 20 & 0 & 0 & 0 & 55.83 & 55.482 & 0.623 \\
\hline 16 & 0.60 & 3.5 & 20 & 0 & 0 & 0 & 57.33 & 55.482 & 3.223 \\
\hline 17 & 0.60 & 3.5 & 20 & 0 & 0 & 0 & 55.34 & 55.482 & -0.257 \\
\hline 18 & 0.60 & 3.5 & 20 & 0 & 0 & 0 & 55.97 & 55.482 & 0.872 \\
\hline 19 & 0.60 & 3.5 & 20 & 0 & 0 & 0 & 56.12 & 55.482 & 1.137 \\
\hline 20 & 0.60 & 3.5 & 20 & 0 & 0 & 0 & 52.66 & 55.482 & -5.359 \\
\hline
\end{tabular}

It seems that an acceptable accordance between the experimental and model-calculated data exists for the proposed model, the average deviation being of $-0.268 \%$, in the admissible limitative range of $-10 \% \div+10 \%$.

Table 5. The results of Student test application in the case of proposed model $(Y)$.

\begin{tabular}{|c|c|c|c|c|c|}
\hline Model coefficient & Coefficient value & Dispersion & $\mathrm{t}$ & $\mathrm{t}_{\text {critical }}$ & Sign \\
\hline $\mathrm{a} 0$ & 55.4820 & 0.348481 & 159.211 & 2.571 & + \\
\hline $\mathrm{a} 1$ & 6.760877 & & 19.40101 & & + \\
\hline $\mathrm{a} 2$ & -2.60577 & & 7.477506 & & + \\
\hline $\mathrm{a} 3$ & 9.522658 & & 27.32621 & & + \\
\hline $\mathrm{a} 11$ & 0.924995 & & 2.654366 & & + \\
\hline $\mathrm{a} 22$ & 1.36351 & & 3.912726 & & + \\
\hline $\mathrm{a} 33$ & -1.79096 & & 5.139347 & & + \\
\hline
\end{tabular}




\begin{tabular}{|c|c|c|c|c|c|}
\hline $\mathrm{a} 12$ & -1.53875 & & 4.415595 & & + \\
\hline $\mathrm{a} 13$ & -0.50625 & & 1.452734 & & - \\
\hline $\mathrm{a} 23$ & 1.14125 & & 3.27493 & & + \\
\hline
\end{tabular}

Analysis of the proposed model. The application of classical optimization methodology leads to the conclusion that the $Y$ function (textile wastewater discoloration degree) has a distinct minimum ( $\mathrm{Y}=45.676 \%$ ), corresponding to $X_{1}^{*}=-6.435, X_{2}^{*}=-3.3423$ and $X_{3}^{*}=+1.5926$. Transposed to real variables, these values correspond to the following values of independent variables: a peat dose of 0.6864 [g per $25 \mathrm{~mL}$ ] (or $27.456[\mathrm{~g} / \mathrm{L}]$ ), a pH of 1.828 , and sorption temperature of $32.75^{\circ} \mathrm{C}$. For the proposed empirical model exists a local maximum ( $\mathrm{Y}=76.24 \%$ ), corresponding to $X_{1} *=+1.682, X_{2} *=0$ and $X_{3} *=0$, and optimal values of real independent variables: a peat dose of 0.936 [g per $25 \mathrm{~mL}$ ] (or $37.44[\mathrm{~g} / \mathrm{L}]$ ), a pH of 3.5 , and sorption temperature of $20^{\circ} \mathrm{C}$. The decision/response function $(Y)$ analysis leads to the conclusion that all $X_{i}$ variables (peat dose, $\mathrm{pH}$ and sorption temperature) have an important influence on the textile wastewater discoloration, fact demonstrated by the values of $X_{1}, X_{2}$ and $X_{3}$ coefficients much higher than unit. The influence of $X_{2}$ variable is almost 2.594 times lower than of $X_{1}$, and 3.654 than of $X_{3}$ for $Y$ decision/response function, and its effect is contrary (the $X_{2}$ decreasing increases the color removal).

The Figures 2, 3 and 4 illustrate the dependence of wastewater discoloration degree $(Y)$ vs. two independent variables (one variable was kept at the basic value) (i.e. $\mathrm{Y}=\mathrm{Y}\left(\mathrm{X}_{1}, \mathrm{X}_{2}, 0\right), \mathrm{Y}=\mathrm{Y}\left(\mathrm{X}_{1}, 0, \mathrm{X}_{3}\right)$ and $\left.\mathrm{Y}=\mathrm{Y}\left(0, \mathrm{X}_{2}, \mathrm{X}_{3}\right)\right)$.

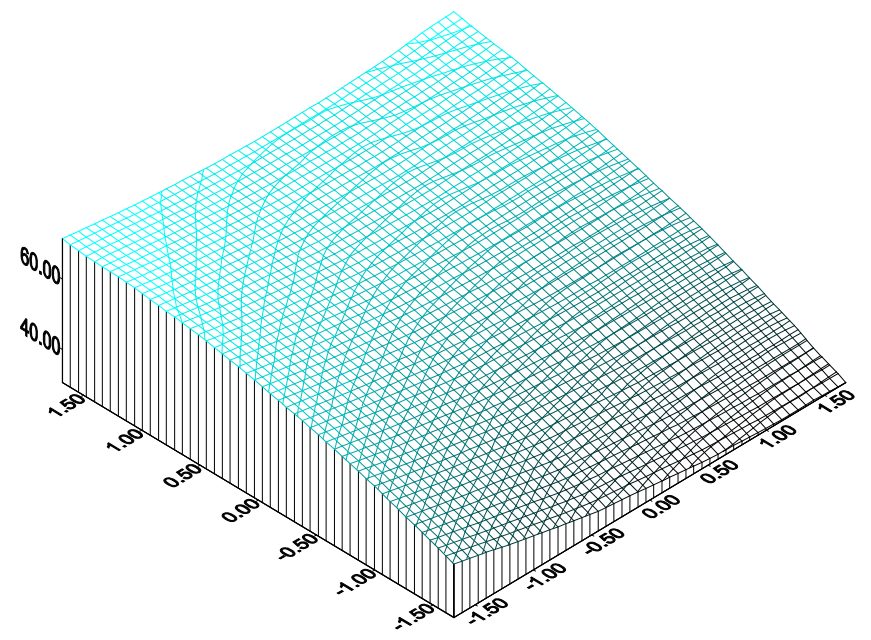

(a) $\mathrm{Y}=\mathrm{Y}\left(0, \mathrm{X}_{2}, \mathrm{X}_{3}\right)$

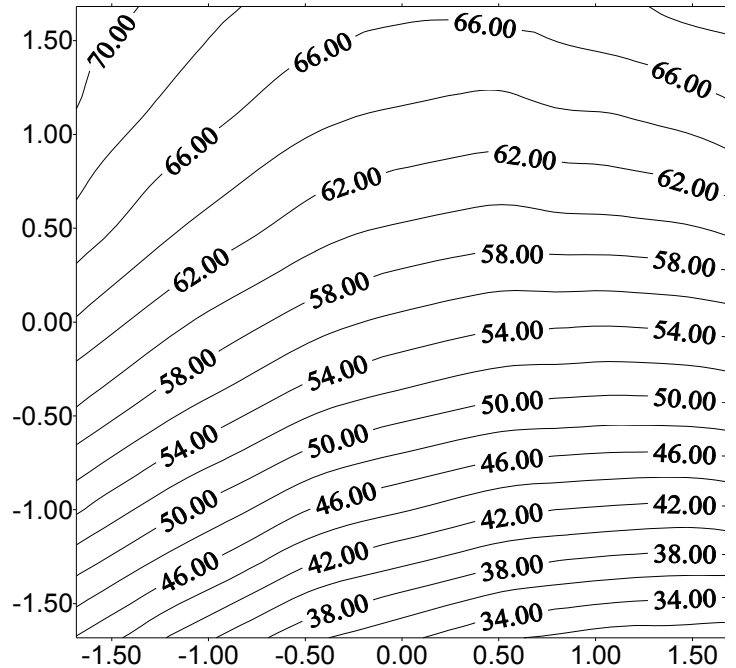

(b) Isolines for $\mathrm{Y}=\mathrm{Y}\left(0, \mathrm{X}_{2}, \mathrm{X}_{3}\right)$

Fig. 2. Variation of wastewater discoloration degree $(Y)$ vs. two independent variables

( $X_{I}$ was kept at the basic value) (i.e. $\left.Y=Y\left(0, X_{2}, X_{3}\right)\right)$.

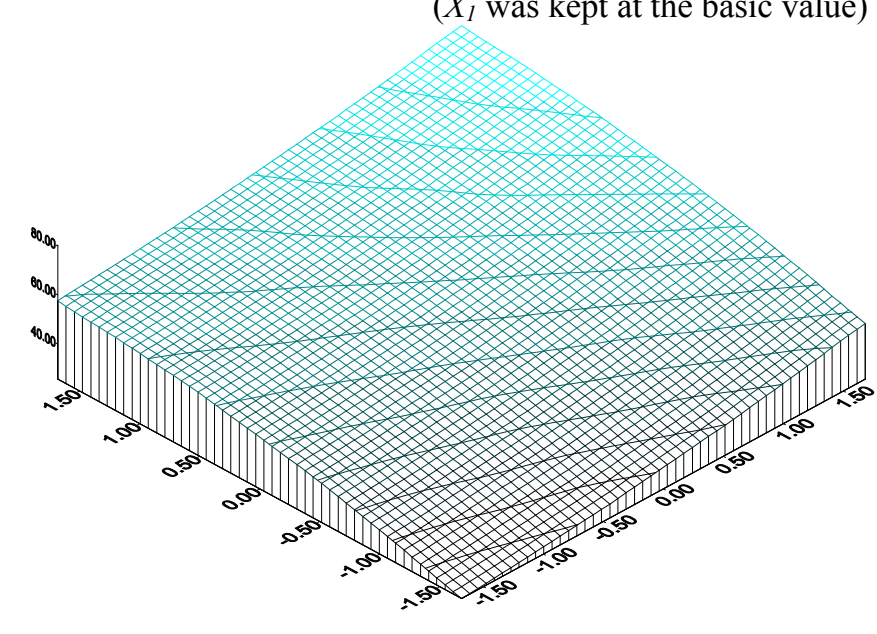

(a) $\mathrm{Y}=\mathrm{Y}\left(\mathrm{X}_{1}, 0, \mathrm{X}_{3}\right)$

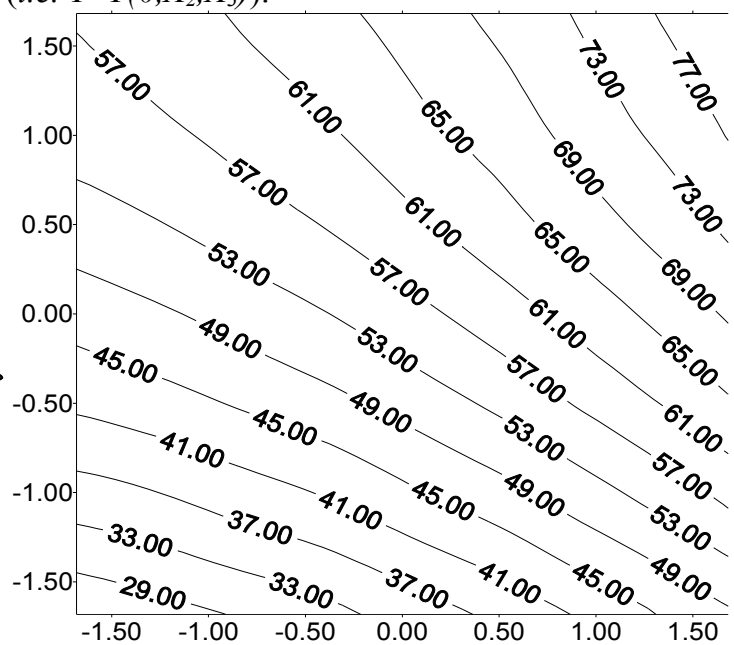

(b) Isolines for $\mathrm{Y}=\mathrm{Y}\left(\mathrm{X}_{1}, 0, \mathrm{X}_{3}\right)$ 
Fig. 3. Variation of wastewater discoloration degree $(Y)$ vs. two independent variables $\left(X_{2}\right.$ was kept at the basic value) (i.e. $Y=Y\left(X_{1}, 0, X_{3}\right)$ ).

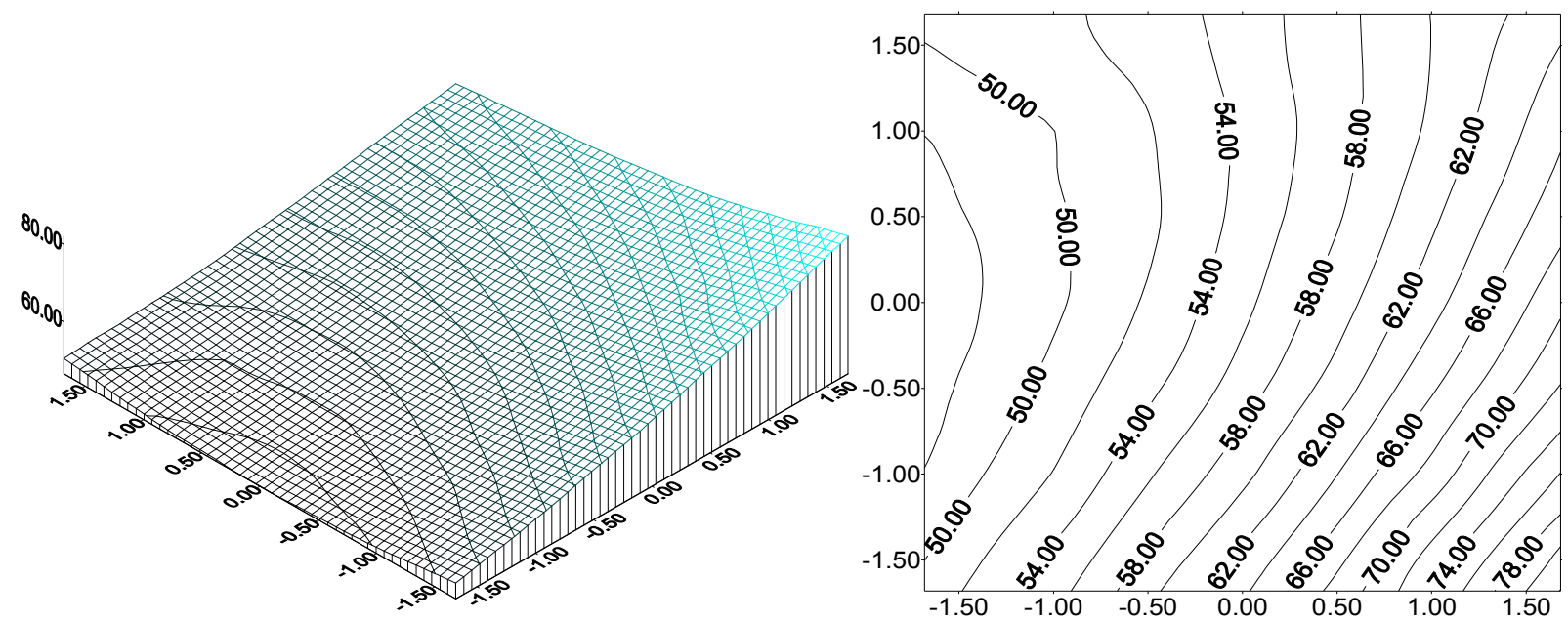

(a) $\mathrm{Y}=\mathrm{Y}\left(\mathrm{X}_{1}, \mathrm{X}_{2}, 0\right)$

(b) Isolines for $\mathrm{Y}=\mathrm{Y}\left(\mathrm{X}_{1}, \mathrm{X}_{2}, 0\right)$

Fig. 4. Variation of wastewater discoloration degree $(Y)$ vs. two independent variables $\left(X_{3}\right.$ was kept at the basic value) (i.e. $\left.Y=Y\left(X_{1}, X_{2}, 0\right)\right)$.

The increase of textile wastewater discoloration degree with the increase of adsorbent dose (amount) is evident in Figure 5a illustrating the variation of $Y$ vs. $X_{I}$. It seems that exists a minimum color removal $(\mathrm{Y}=43.128 \%)$ for $X_{I}{ }^{*}$ $=\quad-3.655$, but also a local maximum $(\mathrm{Y}=62.62 \%$ ) for a peat dose of 0.936 [g per $25 \mathrm{~mL}]$ (or, $37.44[\mathrm{~g} / \mathrm{L}]), \mathrm{pH}=$ 3.5 and $\mathrm{T}_{\text {sorption }}=20^{\circ} \mathrm{C}$ ).

The dependence of color removal vs. $X_{2}\left(X_{1}\right.$ and $X_{3}$ encoding values are 0$)$ indicates a minimum discoloration degree $\left(\mathrm{Y}=54.237 \%\right.$ ) for $X_{2}{ }^{*}=+0.9553$ (i.e. a minimum point for a peat dose of 0.60 [g per $25 \mathrm{~mL}$ ( or, 24 [g/L]), $\mathrm{pH}=3.978$ and $\mathrm{T}_{\text {sorption }}=20^{\circ} \mathrm{C}$ ) (Figure $5 \mathrm{~b}$ ), existing also a local maximum for the highest extreme negative value of $X_{2}$.

The dependence of color removal $(Y)$ vs. $X_{3}\left(X_{1}\right.$ and $X_{2}$ encoding values are 0$)$ indicates a maximum discoloration degree $(\mathrm{Y}=66.662 \%)$ for $X_{3}{ }^{*}=+1.75$ (e.g., a local maximum point for sorption temperature of $34{ }^{\circ} \mathrm{C}, \mathrm{pH}=3.5$ and adsorbent dose of 0.60 [g per $25 \mathrm{~mL}$, or 24 [g/L]) (Figure 5c).

In this paper, the research work was concentrated only to determine the optimal values when it is used in the adsorption stage a relative high quantity of moss peat $(0.263-0.936$ [g per $25 \mathrm{~mL}$ ], or $10.52-37.44$ [g/L]). Thus, it seems that high color removal, or textile wastewater discoloration will be performed for relative high sorbent amounts (i.e. $>0.60$ [g per $25 \mathrm{~mL}$ of sample], or 24 [g/L]), relative low $\mathrm{pH}$ value (i.e. $\mathrm{pH}<=3.5$ ), and sorption temperature of $20^{\circ}-33.5^{\circ} \mathrm{C}$.

Application of direct empirical optimization methodology based on univariant search, and/or gradient methods [15] for the proposed model in this work leads to closed value of the local maximum obtained by classical optimization methodology $\left(\mathrm{Y}=76.24 \%\right.$ ) for values of the three independent variables of: $X_{1} *=+1.682, X_{2}^{*}=0$ and $X_{3} *=0$, meaning a peat dose of 0.936 [g per $25 \mathrm{~mL}$ ] (or $37.44[\mathrm{~g} / \mathrm{L}]$ ), $\mathrm{pH}$ of 3.5, and sorption temperature of $20{ }^{\circ} \mathrm{C}$.

The graphical representations (Figures 4 and 5) permit to observe in the experimental field the variation on isolines, and the maximum point for high color removal, or wastewater discoloration efficiency when some of the independent variables are kept constantly at its basic values. There were used the WinSurf and Excel data processing programs. 

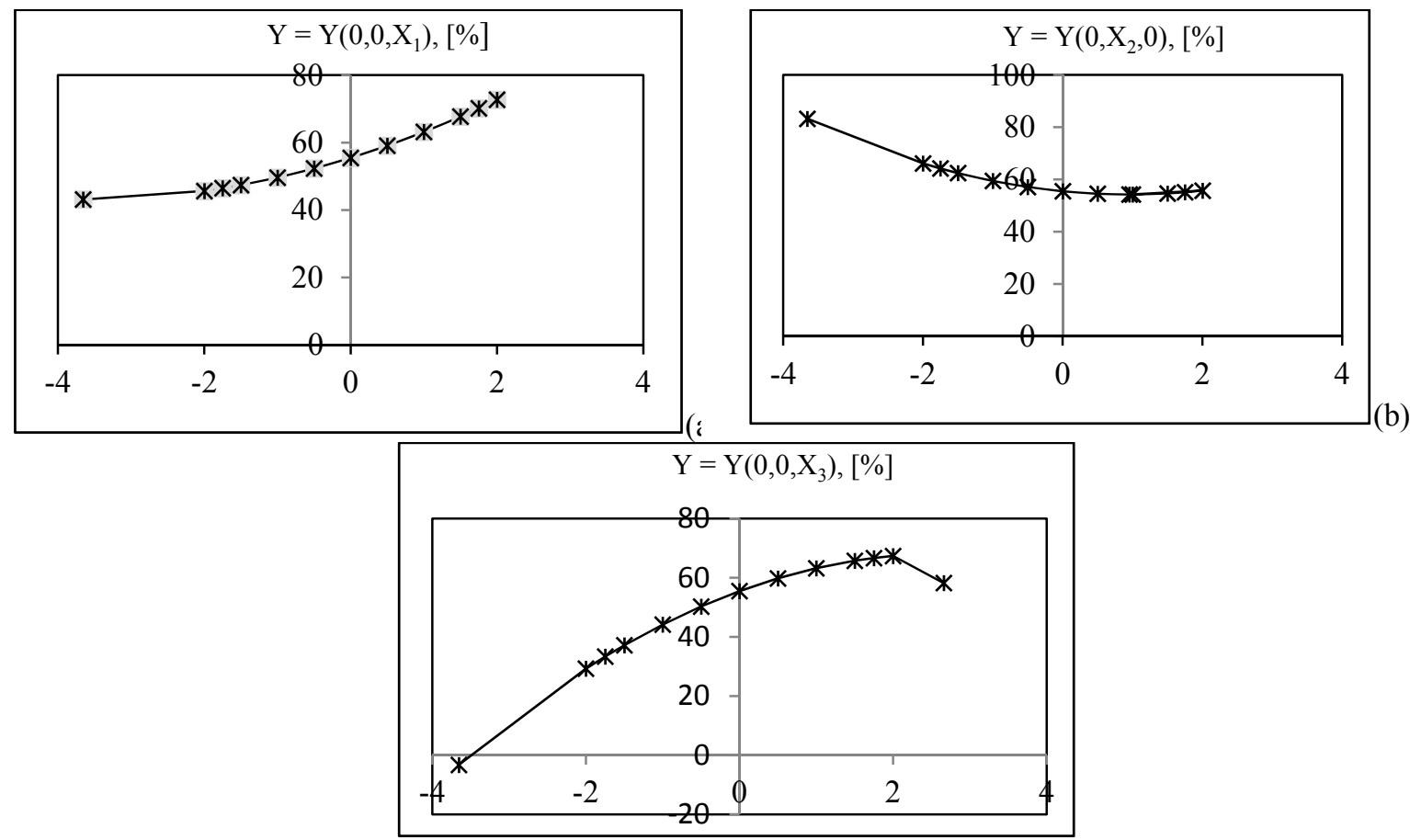

(c)

Fig. 5. Variation of wastewater discoloration degree $(Y)$ vs. one independent variable $\left(X_{i}\right)$ (two variables were kept at the basic value), i.e. (a) $Y=Y\left(X_{1}\right)$, (b) $Y=Y\left(X_{2}\right)$, or (c) $\left.Y=Y\left(X_{3}\right)\right)$.

\section{CONCLUSIONS}

The sorption onto moss peat can be applied with relative good results in the case of real textile wastewater discoloration. An empirical model is proposed by a central active composite rotatable $2^{3}$ design, considering peat dose $\left(X_{1}\right.$, experimental range of 10.52-37.44 [g/L]), $\mathrm{pH}\left(X_{2}\right.$, experimental range of 2.66-4.34) and sorption temperature $\left(X_{3}\right.$, experimental range of $\left.18-35.5\left[{ }^{\circ} \mathrm{C}\right]\right)$ as independent variables, while color removal, or discoloration degree is chosen as optimization criterion (response/decision function, $Y[\%]$ ).

There were performed 20 experiments of textile wastewater adsorption onto moss peat, and each time the treated wastewater was characterized consisting its principal quality indicators expressing the color, sum organic content, fixed residues, total suspended solids, in order to obtain especially the highest discoloration performance, or color removal higher than $70-80[\%]$.

The experimental data were processed for mathematical model proposal (coefficients' statistical calculation), significance and importance of each variable was analyzed and appreciated (i.e. Fisher constant $(F)$ and test $\left(F_{c}\right)$, multiple correlation coefficient $\left(R_{Y x I x \times 3}\right)$, Student test $\left.(t)\right)$, and a classical mathematical optimization methodology applied. The local optimal values found for the three studied independent variables correspond to a peat dose of 0.936 [g per $25 \mathrm{~mL}$ ] or $37.44[\mathrm{~g} / \mathrm{L}], \mathrm{pH}$ of 3.50 , and temperature of $20^{\circ} \mathrm{C}$ for a maximal wastewater discoloration degree of $76.24 \%$.

The graphical representation of different variations of discoloration degree $v s$. one or two selected independent variables permits localization of optimal variation field of each studied variables. This modeling and optimization study represents a pertinent case study, which analyzes the discoloration performance of a real textile wastewater by application of an empirical experimental design planning based on a single adsorption treatment stage onto a Romanian natural solid adsorbent, Sphagnum moss peat.

The results are encouraging (meaning, discoloration degree higher than 70-76 [\%]), and recommend the continuity of modeling and especially of optimization study by other improved or much adequate analytical, empirical, programmed (controlled) methods. 


\section{REFERENCES}

[1] Ataei, A., Lee, K.S., Lim, J.J., Liu, M.J., Kang, O.Y., Oh, T.S., Yoo, C.K., A review on environmental process engineering, Int. J. Environ. Res, vol. 5, no. 4, 2011, p. 875-890.

[2] Charpentier, J.C., Among the trends for a modern chemical engineering: CAPE an efficient tool for process intensification and product design and engineering, Computer Aided Chemical Engineering, vol. 24, 2007, p. 1118.

[3] Yoo, C.K., Kim, D.S., Cho, J.H., Choi, S.W., Lee, I., Process system engineering in wastewater treatment process, Korean J. Chem. Eng., vol. 18, no. 4, 2001, p. 408-421.

[4] Wilderer, P.A., Bungartz, H., Lemmer, H., Wagner, M., Keller, J., Wuetyz, S., Modern scientific methods and their potential in wastewater, Water Resourse, vol. 36, no. 2, 2002, p. 379-393.

[5] Zaharia, C., Amarandei, V., Murarasu, A., The preliminary study of decoloration by sorption onto modified coal ash with lime of a real textile effluent, Proceedings of International Conference of Applied Sciences, Chemistry and Chemical Engineering - CISA, Seventh Edition, Bacau, 2013, p. 116-122.

[6] Zaharia, C., Amarandei, V., Muresan, A., Comparative overview of different physical-chemical treatments applied for real textile effluents, Advanced Materials Research, vol. 1036, 2014, p. 58-64.

[7] Zaharia, C., Application of waste materials as 'low cost' sorbents for industrial effluent treatment. A comparative overview, International Journal of Materials \& Products Technology, vol. 50, no. 3/4, 2015, p. 16801689.

[8] Zaharia, C., Suteu, D., Coal fly ash as adsorptive material for treatment of a real textile effluent: operating parameters and treatment performance, Environmental Science and Pollution Research, vol. 20, no. 4, 2013, p. 2226-2235.

[9] Zaharia, C., Suteu, D., Muresan, A., Options and solutions for textile effluent decolourization using some specific physico-chemical treatment steps, Environmental Engineering and Management Journal, vol. 11, no. 2, 2012, p. 493-509.

[10] Zaharia, C., Application of a physico-chemical treatment based on adsorption for industrial effluents. A case study, Proceeding of the 16th International Conference - Modern Technologies, Quality and Innovation ModTech 2012 - New Face of T.M.C.R., Sinaia, 2011, vol. II, p. 1069-1072.

[11] Dartu, L., Zaharia, C., Carja, G., Application of new synthesized materials based on anionic clays for industrial effluent decoloration, Advanced Materials Research, vol. 837, 2014, p. 271-276.

[12] Zaharia, C., Diaconescu, R., Surpateanu, M., Study of flocculation with ponilit GT-2 anionic polyelectrolyte applied into a chemical wastewater treatment, Central European Journal of Chemistry, vol. 5, no. 1, 2007, p. 239256.

[13] Zaharia, C., Suteu, D., Optimization study of Orange 16 dye sorption from aqueous systems using sawdust wastes, Chem. Bull. 'POLITEHNICA' Univ. (Timisoara), series: Chemistry and Environmental Engineering, vol. 56, no. 1,2011 , p. 24-28.

[14] Macoveanu, M., Nicu, V., Bazele tehnologiei chimice. Metodologia modelarii matematice in industria chimica, Ed. Rotaprint a Universitatii Tehnice "Gheorghe Asachi”, Iasi, 1987.

[15] Cojocaru, C., Cretu, V.C., Preda, C., Macoveanu, M., Cretescu, I., Response surface methodology applied for investigation of diesel oil spill removal from surface water using textile sorbents, Journal of Environmental Protection and Ecology, vol. 11, no. 2, 2010, p. 643-656.

[16] Cojocaru, C., Macoveanu, M., Cretescu, I., Peat-based sorbents for the removal of oil spills from water surface: Application of artificial neural network modeling, Colloids and Surfaces A: Physicochemical and Engineering Aspects, vol. 384, no. 1-3, 2011, p. 675-684.

[17] Betianu, C., Caliman, F.A., Gavrilescu, M., Cretescu, I., Cojocaru, C., Poulios, I., Response surface methodology applied for Orange II photocatalytic degradation in $\mathrm{TiO}_{2}$ aqueous suspensions, Journal of Chemical Technology and Biotechnology, vol. 83, no. 11, 2008, p. 1454-1465.

[18] Secula, M.S., Cretescu, I., Cagnon, B., Manea, L.R., Stan, C.S., Breaban, I.G., Fractional factorial design study on the performance of GAC-enhanced electrocoagulation process involved in color removal from dye solutions, Materials, vol. 6, no. 7, 2013, p. 2723-2746.

[19] Cretescu, I., Diaconu, M., Cojocaru, C., Benchea, R.E., Pohontu, C., Removal of Dunkel Blau dye from aqueous solutions by fungal and peat biomass in batch mode, Environmental Engineering and Management Journal, vol. 9, no. 1, 2010, p. 107-112.

[20] Secula, M.S., Cagnon, B., Creţescu, I., Diaconu, M., Petrescu, S., Removal of an acid dye from aqueous solutions by adsorption on a commercial granular activated carbon: equilibrium, kinetic and thermodynamic study, Scientific Study \& Research - Chemical Engineering, Biotechnology, Food Industry, vol. 12, no. 4, 2011, p. 307322. 
[21] Cojocaru, C., Cretescu, I., Macoveanu, M., Diaconu, M., Kicsi, A., Studies on diesel oil spills removal from water surface using peat. Process modelling and optimization, Environmental Engineering and Management Journal, vol. 3, no. 3, 2004, p. 247-257.

[22] Poroch-Seritan, M., Gutt, S., Gutt, G., Cretescu, I., Cojocaru, C., Severin, T., Design of experiments for statistical modeling and multi-response optimization of nickel electroplating process, Chemical Engineering Research and Design, vol. 89, no. 2, 2011, p. 136-147. 